Rossella Esther Cerchia*

\title{
A Comparative Viewpoint on Illegal Contracts: In Favor of Flexibility and Proportionality
}

https://doi.org/10.1515/gj-2021-0001

Published online March 25, 2021

\begin{abstract}
In today's society, a dense network of laws and regulations presides the actions of all people. And it is so extensive that any number of activities - including the formation of contracts - is capable of breaking the law. This is why it is even more important, nowadays, to reconsider the issue of contracts that violate legal rules. The trend in favor of flexible remedies reveals that the rigidity of the more traditional solutions might not be the best choice in this day and age.
\end{abstract}

Keywords: comparative contract law, illegal contracts, illegality, immoral contracts

\section{Introduction}

In today's society, a dense network of laws and regulations presides all people's actions. Moreover, it is so extensive that any number of activities - including contracts - is capable of breaking the law. The legal remedies for these infringements have remained tied to a society of the past, more or less remote, and are not appropriate for our times. Thus, it is even more important to reconsider the rules for contracts that violate legal rules in such a context.

This article, by examining illegal contracts in a comparative perspective, ${ }^{1}$ seeks to highlight the importance of mitigating the principle of equivalence

1 On comparative methods, see generally Antonio Gambaro and Rodolfo Sacco, Sistemi Giuridici Comparati, 4th ed. (Torino: Utet Giuridica, 2018), 3; Antonio Gambaro, "Diritto Comparato," in Novissimo Digesto Italiano, vol. 2 (Torino: UTET, 1980), 1165; Antonio Gambaro, "Il diritto comparato in Italia e nel mondo occidentale: una introduzione al dialogo 'Civil Law - Common Law'," Riv. Trim. Dir. Proc. Civ., (1983): 1528; Antonio Gambaro, Pier Giuseppe Monateri and Rodolfo Sacco, “Comparazione Giuridica," in Digesto IV, vol. 3 (Torino: UTET, 1988), 48; Antonio Gambaro, "The Trento Theses," Global Jurist 4, no. 1 (2004); Michele Graziadei, "The Functionalist Heritage," in Comparative Legal Studies: Traditions and Transitions, ed. P. Legrand and R. Munday,

*Corresponding author: Rossella Esther Cerchia, Department of Private Law and Legal History, University of Milan, via Festa del Perdono 7, 20122 Milan, Italy, E-mail: rossella.cerchia@unimi.it 
between illegality and nullity (even if not all violations of the law result in nullity) before discussing the need to disregard the ex turpi causa non oritur actio ${ }^{2}$ as a general rule.

After a brief outline of what defines a fluid category of illegal contracts, this contribution compares more flexible approaches to contractual illegality, which considers different factors and supplies different remedies, with more rigid ones, a sort of "automatism" between illegal contract and a specific remedy, which principal argument in its favor is generally seen as the predictability and certainty of the case law output.

It is a multi-step process composed of various types of steps that may be summarized as follows. First, the court must interpret both the contract and the mandatory rule. The issues surrounding such interpretation have been so thoroughly explored that the complexity of the hermeneutic activity is now wellknown, and its results are not always linear. Secondly, since mandatory law and contract are two hierarchically ordered sets of rules, it must be ascertained whether the content of the contract can be adapted in such a way as not to conflict with the content of the mandatory rule. If it is found that the contract cannot be saved by interpretation, hetero-integration (another relevant general issue) or partial nullity, then it must be examined whether nullity (the doctrine of "virtual nullity" or "impliedly prohibited contract" comes into play) is the adequate remedy for the policy purposes pursued by the mandatory rule.

If the court determines that the contract is, in fact, null and void, it is then necessary to verify whether the consequent remedy of soluti retentio ${ }^{3}$ is adequate, or whether this remedy is too severe to provide an appropriate and proportionate solution.

Rulings characterized by balance and proportionality between the remedies, the circumstances of the case and the interests at stake, is the outcome of complex operations that require an appropriate legal apparatus and presuppose that the judge has many "arrows available for his bow." Not only: the necessary

(Cambridge: Cambridge University Press, 2003), 100-127; Michele Graziadei, "Legal Transplants and the Frontiers of Legal Knowledge," Theoretical Inquiries in Law 10, no. 2 (2009): 723; Mauro Bussani and Ugo Mattei, "The Common Core Approach to the European Private Law," Columbia Journal of European Law 3 (1997-1998): 339. See Mark Van Hoecke, "Methodology of Comparative Legal Research," Law and Method, (2015): 1-35 (providing a short overview and offering references on different methods in comparative research).

2 Ex turpi causa non oritur actio means that no action can be based on a disreputable cause. Nemo auditor propriam turpitudinem allegans has almost the same meaning.

3 Soluti retentio translates literally to "retention of the payment." 
predictability of the law implies that, if on the one hand there is flexibility and elasticity, on the other hand the criteria that guide the award choices are known.

This article proceeds by extending the field of investigation to the Western Legal Tradition (WTL) ${ }^{4}$ viewpoint by discussing distinct national laws and soft law instruments. The survey also considers the influence of different "legal formants," 5 as well the discrepancy between "law in the books" and "law in action."6

The research area is limited to the last steps of the process mentioned above and the two said scenarios. In the first scenario (i.e., the one related to contracts that infringe mandatory rules when the effect of the infringement is not provided), the flexible approach is played by model laws - such as the Draft Common Frame of Reference, UNIDROIT Principles of International Commercial Contracts, and the Principles of European Contract Law - that focus on proportionality between the infringement committed and the legal remedy. The more rigid approach is "interpreted" by Art. 1418 (1) of the Italian civil code (hereinafter “c.c. It.”), according to which the court must choose between two extremes: the contract is either valid or null and void. ${ }^{7}$

The second scenario is precisely the one related to the action of restitution when the parties of an illegal contract are in pari delicto. ${ }^{8}$ The automatic denial of restitution represents the rigid approach. An automatism of such kind may be found in the Italian civil code establishing that restitution is unavailable if the contract is immoral. ${ }^{9}$ Instead, flexible approaches adopted in different national laws attempt to identify fair proportionality between remedies and different factors. ${ }^{10}$ Two relatively recent decisions highlight these two divergent

4 See generally Antonio Gambaro, "Western Legal Tradition," in New Palgrave Dictionary of Economics and the Law, ed. Peter Newman (Houndmills: Palgrave Macmillan, 1998), 686.

5 Rodolfo Sacco, "Legal Formants: A Dynamic Approach to Comparative Law," The American Journal of Comparative Law 39 (1991): 1; Id., "Legal Formants: A Dynamic Approach to Comparative Law (Installment II of II),” The American Journal of Comparative Law 39 (1991): 343.

6 The expression is taken from Roscoe Pound, "Law in Books and Law in Action," American Law Review 44, no. 1 (1910): 12.

7 The very relevant topics of modification of contract and doctrine of severability (or partial nullity) to "save" an illegal contract are outside the scope of this article and will not be discussed here.

8 The rules related to the locus poenitentiae doctrine and the ones related to the parties that are not in pari delicto (two of the most well-known exceptions to the general rule in favor of lack of restitution) are outside the scope of the present contribution and will not be discussed.

9 Immorality is a sub-category of illegality, as later explained in Section 4.

10 On the soluti retentio as an ancient dilemma within Western Legal Traditions, see Antonio Gambaro, "Rule-Based Approach versus Range of Factors Approach,” 123. 
approaches, one in the Italian Court of Cassation and one in the United Kingdom Supreme Court (UKSC).

The trend in favor of flexibility reveals that the more traditional remedies' rigidity might not be the best choice in this day and age. ${ }^{11}$ Responding to the violation of mandatory rules with the complete "demolition" of the contract (i.e. nullity) might mean using an ax even when the appropriate tool could be the chisel. The automatism that links unavailability of restitution to an univocal criterion, such as "immorality" or "illegality," seems to be an oversimplification that has lost meaning. The central claim of rigid approaches, which state that allowing flexibility in establishing remedies could lead to the unpredictability of results and disrupt legal certainty, does not justify their survival.

The article attempts to highlight that extensive "staturification"12 of modern legal systems recommends avoiding "legal reductionism"13 in favor of a more complex legal apparatus.

\section{Illegal Contracts: A Fluid Category}

Jurists around the world feel familiar with the concept of "illegal contracts."14 Simply put, these terms immediately recall the limits placed on party autonomy or

$11 C f$. Barbara Vari, "Il sistema della illegality del contratto," in Il DCFR: lessici, concetti e categorie nella prospettiva del giurista italiano, ed. Carlo Marchetti, vol. 3 (Torino: Giappichelli, 2012), 103. 12 Guido Calabresi, A Common Law for the Age of Statutes (Cambridge, Massachusetts; London, England: Harvard University Press, 1982) (coining the expression "staturification" to show that statutes have become the primary sources of law).

13 The reference is to the theory that reduces complex data and phenomena to simple terms.

14 Due to the vastness of the literature on illegal and immoral contracts, in the context of the present research, it is sufficient and appropriate to cite a few contributions that have dealt with these issues from a comparative perspective. See e.g., Konrad Zweigert and Hein Kötz, Introduction to Comparative Law, trans. Tony Wier, ed. 3rd Rev. (Oxford: Clarendon Press, 1998), 380-387 (discussing illegality and immorality in a comparative perspective); Birke Häcker, "The Impact of Illegality and Immorality on Contract and Restitution from a Civil Angle," in Illegality After Patel $v$. Mirza, eds. Sarah Green and Alan Bogg (Oxford: Hart Publishing, 2018), 331-370 (providing a comparative analysis of illegality in contract law from a civil perspective); Hein Kötz, European Contract Law, 2nd ed. (Oxford: Oxford University Press, 2017), 336 (offering a comparative analysis of illegality in contract law); Sonya Meier, "Illegality," in Commentaries on European Contract Laws, eds. Nils Jansen and Reinhard Zimmermann (Oxford University Press, 2018), 1887-1907 (examining illegal contracts in a European perspective); Gambaro, "Rule-Based Approach versus Range of Factors Approach," 123 (discussing soluti retentio in the WLT); Vari, "Il sistema della illegality," 89 (providing a detailed overview of soft law instruments); Paolo Gallo, "Ripetizione dell'indebito," Dig. Disc. Priv., Sez. civ., Aggiornamento (2012-2019): 880 (discussing contracts against good morals); Paolo Gallo, Introduzione al diritto comparato, 3rd ed., vol. 2: Istituti giuridici (Torino: G. Giappichelli Editore, 2018), 341 ff. (discussing restitution in different legal systems). 
freedom of contract by substantive law, public policy, or good morals. To be more specific, in civil law systems, illegal contracts may be described as contracts that violate mandatory rules, public order, and good morals (when the latter are not included in the notion public order ${ }^{15}$ ). These kinds of contracts are often linked to illicit causa or illicit "object" of the contract, sometimes even to illicit motives of the contract. ${ }^{16}$ The approach is similar in common law where contracts are often rendered illegal by statutes, common law principles, or described as unenforceable contracts that are rendered void either by statute or common law (including public policy). ${ }^{17}$

15 Very generally, it may be affirmed that public policy and public order serve the same function: the former in common law countries, while the latter in the civil law countries. See generally Kent Murphy, "The Traditional View of Public Policy and Order Public in Private International Law," Ga. J. Int'l \& Comp. L. 11 (1981): 591.

16 In the civil codes, influenced by the French civil code of 1804, the idea of "illegality" was often linked to the concept of "causa" and "object." For instance, in Italy, Art. 1325 c.c. It. denotes "causa" as one of the essential requisites of a contract and provides that "causa" must be lawful. According to Art. 1343 c.c. It., "the causa is unlawful when it is contrary to mandatory rules, public policy or morals." The causa is also considered unlawful (and the contract is void) when attempts to "defraud" the law. This happens when "the contract constitutes the means for evading the application of a mandatory rule.” (Art. 1344 c.c. It.). Then, pursuant to Art. 1346 c.c. It., the object must be lawful. The object is lawful when it is not contrary to mandatory rules, public policy or morals. It is often difficult to ascertain whether it is the object or the causa of a contract that is unlawful, so scholars often speak of "unlawful contract" to include both cases. See Cenini Marta and Rossella Esther Cerchia, Cases and Materials on Italian Private Law, (Milano: Giuffrè, 2016) (offering an overview on Italian private law for English readers). See also Antonio Gambaro, "Sintesi conclusiva in tema di causa e contratto," in Causa e contratto nella prospettiva storicocomparatistica. Il Congresso Internazionale Aristec, ed. Letizia Vacca (Torino: Giappichelli, 1997) (discussing causa in a comparative perspective). Interestingly, in 2016, the French reform of the Civil Code abandoned the two notions of cause and object. The two concepts seem to be replaced with the single concept of "content" of the contract. The new Art. 1128 c.c. Fr. states that a contract, to be legal, must have "Un contenu licite et certain." The new Art.1162 c.c. Fr. adds that the contract cannot derogate from the "ordre public ni par ses stipulations, ni par son but, que ce dernier ait été connu ou non par toutes les parties." See generally, Peter Rosher, "French Contract Law Reform," Bus. L. Int'l 17, (2016): 59; Solène Rowan, "The New French Law of Contract," Int. \& Comp. L. Q. 66, no. 4 (2017): 59 (both providing a detailed recount of the reform of French contract law).

17 Cf., Patrick Selim Atiyah, "An Introduction to the Law of Contract," 38 (3d ed. 1981) in CONTRACT definition, in Black's Law Dictionary, ed. Bryan A. Garner, 11th ed. (Toronto: Thomson Reuters, 2019) (affirming “An illegal contract is exceptionally difficult to define. It does not merely mean a contract contrary to the criminal law, although such a contract would indubitably be illegal. But a contract can well be illegal without contravening the criminal law, because there are certain activities which the law does not actually prohibit, but at the same time regards as contrary to the public interest and definitely to be discouraged, for instance, prostitution. While a void contract is not necessarily illegal, an illegal contract is often void. However, the consequences of an illegal contract differ somewhat from those usually produced by a simply void contract, so 
Although the category of "illegal contracts" seems very well-known, and this area of law might be, at first glance, straightforward, a more in-depth look reveals something different. ${ }^{18}$ It could be defined as an "optical effect." In particular, if the category's content is examined by reading legal literature that abstractly describes this content, one might get the impression of a certain coherence. However, if one examines the case law, the sensation is that of being faced with a bunch of totally different cases that have almost nothing in common. ${ }^{19}$ For instance, contracts to commit a crime, contracts for employment of undocumented workers, legal contracts which performance is illegal, contracts tainted with corruptions, contracts that violate regulations. Despite the different interests at stake, these contracts could be simply classified as illegal.

It seems that the term "illegal contract" represents a sort of label to indicate a wide variety of cases whose only common feature is that they contain some element of illegality. The English expression "contracts tainted with illegality," which may sound strange to a civil lawyer's ear, perfectly describes the phenomenon. This is why many authors divide the category of illegal contracts into a series of sub-categories. However, this sectioning process seems more appropriate for didactic purposes ${ }^{20}$ than aimed at linking specific legal effects to each sub-

illegal contracts are usually accorded separate treatment"). Cf. also, Lindy Willmott et al., Contract Law, 5th ed. (Victoria, South Melbourne: Oxford University Press, 2018), 646 (affirming: “A contract may be rendered 'illegal' in two ways: it may be prohibited by statute, or it may be contrary to public policy at common law. However, not all contracts that contravene a statute or are contrary to public policy are properly describe as illegal. These contracts may instead be referred as being 'void' ").

18 The difficulty of handling the issue of illegality in contract law is well-known and was described as a "notoriously knotty territory" in Parking Eye Ltd v. Somerfield Stores Ltd, 2012, EWCA Civ 1338, Q.B. 840 at 28 (2013).

19 E.g., Ewan McKendrick, Contract Law, 13th ed. (London: Red Globe Press, 2019), 279 (pointing out that "illegal contracts come in so many different shapes and sizes that is difficult to find an appropriate classification for all the cases."); Saul Schwartz, "Law Reform Commission of British Columbia, Report on Illegal Contracts," Can. Bus. L.J. 10 (1985): 83 (affirming "Few areas of the common law are so conceptually disorganized as the law relating to illegal contracts. There is confusion about the use of the term 'illegal' when applied to contracts, controversy about the effects of illegality and uncertainty about the boundaries of the doctrine. Not surprisingly, there is also no settled classification of the various types of illegal contracts"). The difficulties associated with handling the category of illegal contracts are not limited to the Western Legal Tradition. See e. g., Nilima Bhadbhade, "India," in International Encyclopedia of Law: Contracts, ed. Jacques H. Herbots (Alphen aan den Rijn, The Netherlands: Kluwer Law International, 2016) (stating "The law relating to illegality affecting contracts in complex and has grown in an unsystematic manner"). 20 McKendrick, Contract Law, 270 (looking at different classifications, affirming that the "categorisation in undertaken largely for the purpose of ease exposition"). 
category. ${ }^{21}$ Furthermore, the sub-categories of contracts contrary to public policy and good morals, exposed by their very nature to the continuous evolution of society time, make the boundaries of illegal contracts a fluid state. If these latter subcategories are fluid, both the internal scans and the external borders of the illegality category become fluid, and a fluid category loses any ordering capacity.

Also, the terminology is sometimes a little ambiguous for jurists of different traditions. Even if the expression illegal contracts is very common both in case law and literature, from time to time, in English as lingua franca, ${ }^{22}$ the term "unlawful",23 or "prohibited" 24 contracts is preferred. ${ }^{25}$ In the American Restatement (First) of Contract $\S 512$ (1932), the expression "illegal bargain” replaced "illegal contract," probably for the contradiction between the concept of contract and unenforceability. ${ }^{26}$ Then, the Restatement (Second) of Contracts $\S 178$ (1981) opted for a more generical indication (without any reference to the illegality) of a promise or term that might be unenforceable on the grounds of public policy. ${ }^{27}$ Moreover, the civil lawyer who uses the terminology related to invalidity in contract law in a very straightforward manner is disoriented by common law lexicon, where the use of the terms illegal, void, and unenforceable are not always linear. ${ }^{28}$ Likewise, the civil

21 See J. W. Carter, Contract Law in Australia, 6th ed. (Sidney: LexisNexis Butterworths, 2013), 549-550 (stating "[It] seems to be generally accepted that it is impossible to reconcile all the cases on illegality. [...] Inconsistencies are particularly in evidence where the consequences of illegality are in issue").

22 See generally on the idea of lingua franca Antonio Gambaro, "La riforma del diritto italiano delle obbligazioni e dei contratti nella prospettiva del diritto europeo," in "Il diritto delle obbligazioni e dei contratti: verso una riforma? Le prospettive di una novellazione del Libro IV del Codice Civile nel momento storico attuale," in Atti del convegno per il cinquantenario della Rivista di Diritto Civile (Padova: CEDAM, 2006).

23 See for instance, Regulation (EC) No. 593/2008, of the European Parliament and of the Council of 17 June 2008 on the law applicable to contractual obligations (Rome I), Art. 9 (3) on overriding mandatory provisions.

24 The wording "prohibited contract" is, for instance, preferred by Jan M. Smits, Contract Law, a Comparative Introduction, 2nd ed. (Cheltenham: Edward Elgar Pub., 2017).

25 For instance, the drafters of the Draft Common Frame of References (DCFR) chose to have a descriptive and neutral title (Infringement of fundamental principles or mandatory rules) for section III. Thus, abandoning the reference to illegality found in the PECL and in the third edition of the Unidroit Principles. See Vari, "Il sistema della illegality del Contratto," 91.

26 See Juliet P. Kostritsky, "Illegal Contracts and Efficient Deterrence: A Study in Modern Contract Theory,” Iowa Law Review 74, no. 4 (1988): 115.

27 On this point, see Richard A. Lord, Williston on Contracts, ed. 4th, vol 5, (Lawyers Cooperative Publishing, 2009) § 12:4.

28 Cf., Elizabeth Macdonald and Ruth Atkins, Koffman \& Macdonald's Law of Contract, 9th ed. (Oxford: Oxford University Press, 2018), 371 (pointing out that the distinction between illegal and void contract is not universally accepted). 
law distinction between "illicit" and "illegal" contracts might seem odd to a common law jurist. ${ }^{29}$ Analyzing critical issues that emerge in legal translation highlight the difficulties in understanding, ${ }^{30}$ but these difficulties, at their core, reveal the divergences related to the profound way of conceiving the contract. These divergences are almost imperceptible when dealing with the contract's positive effects, the contract's interpretation, or the management of the contractual relationship. Nevertheless, they become relevant substrate problems when dealing with the invalidity of the promise or contract meant as in idem placitum consensus; ${ }^{31}$ hence the difficulties of comparison. ${ }^{32}$

The subject-matter of illegal contracts is broad and complex, with profiles that are difficult to define: identifying rules to navigate through this Dantean dark forest appears to be a very complex operation.

\section{Infringement of Mandatory Rules: Some Flexible Approaches}

The equivalence of contract contra legem ${ }^{33}$ and a null contract is widespread. This combination seems to have its roots in Roman Law, even if during the classical era

29 For instance, in the Italian legal system, illicit contracts are related to Arts. 1343-46 and 1418(2) c.c. It., whereas illegal contracts are related to Art. 1418(1) c.c. It.

30 On problems related to legal translation, see generally, Rodolfo Sacco and Piercarlo Rossi, Introduzione al diritto comparato, 7th ed. (Torino: Utet Giuridica, 2019); Rodolfo Sacco, "Traduzione Giuridica," in Digesto, Discipline Privatistiche - sezione civile, 4th ed. (Torino: Utet Giuridica, 2000), 722-740; Id., "La Traduzione Giuridica," in Il linguaggio del diritto, eds. Uberto Scarpelli, Mario Jori, and Paolo Di Lucia, (Milano: LED Edizioni Universitarie, 1994), 475-500; Id., "Langue Et Droit,” in Langue Et Droit XV Congrès International de Droit Comparé, ed. Erik Jayme (Bristol: Bruylant, 2000), 223-373; Id., "Language and Law," in Ordinary Language and Legal Language, ed. Barbara Pozzo (Milano: Giuffrè, 2005), 1-23; Barbara Pozzo, "La Traduttologia Giuridica tra passato e presente," in Lingua e Diritto: Oltre l'Europa, ed. Barbara Pozzo (Milano: Giuffrè, 2014); Valentina Jacometti and Barbara Pozzo, Traduttologia e linguaggio giuridico, (Padova: CEDAM 2018); Barbara Pozzo, "Comparative Law and Language," in The Cambridge Companion to Comparative Law, eds. Mauro Bussani and Ugo Mattei, (Cambridge: Cambridge University Press, 2012), 88-114; Simone Glanert, De La Traductibilité Du Droit (Dalloz, 2011), 77-374; Curran Vivian Grosswald, “Comparative Law and Language," in The Oxford Handbook of Comparative Law, eds. Mathias Reimann and Reinhard Zimmermann, 1st ed. (Oxford: Oxford University Press, 2012).

31 The expression refers to the notion of "meeting of the minds."

32 Portions of the discussion in this section is adapted from Rossella Esther Cerchia, "Alcune riflessioni in tema di Illegal contracts," Annuario di Diritto Comparato e di Studi Legislativi (2020): $377 \mathrm{ff}$.

33 Contra legem is a Latin phrase which literally means "against the law." 
of Roman Law, illegality did not necessarily make contracts null as only the infringements of leges perfectae had this effect. ${ }^{34}$ It was the Lex Non dubium of 439 that established the rule that contracts that violated legal prohibition were null. ${ }^{35}$ Moreover, whatever its actual operation, the European ius commune maintained this combination (at least at the lexical level) and eventually codified it in various civil codes. $^{36}$

A last word on the categories of the contractual invalidity. The well-known dichotomy between nullity (or absolute nullity) and annullability (or relative nullity $)^{37}$ developed in a laissez faire economy with minimum governmental interference. These categories might not be appropriate remedies in modern systems where interventionist policies have given rise to an intricate pattern composed by default rules, mandatory rules, and then, on a translational level, by compulsory rules, overriding mandatory provisions and rules of public order. ${ }^{38}$

The perspective used here is to examine this combination, focusing on the contracts that violate mandatory rules when the rule itself does not provide the effect of the infringement, and evaluating the different degrees of flexibility offered by the law to deal with it.

34 In Roman law, illegality did not necessarily make contracts null and void. Three different types of law differed in this context: leges imperfectae, leges minus quam perfectae, and leges perfectae. Only violations of leges perfectae were sanctioned with nullity. However, as time went by, leges perfectae became more and more common and the aforementioned division lost its importance. See Reinhard Zimmermann, The Law of Obligations: Roman Foundations of the Civilian Tradition (Oxford: Claredon Press, 1996), 697-1312 (providing a historical overview on illegality in contract law); Häcker, “The Impact of Illegality,” 341 (discussing illegality in contract law from a historical perspective).

35 Meier, "Illegality,” 1887-1907; Häcker, “The Impact of Illegality,” 341.

36 Despite of the fact that many civil codes generically provided that contracts against mandatory rules were null and void, the actual operation of such rules has always been the result of a process of interpretation, integration, severance (or partial nullity) to save, within certain limits, the contract. Even systems which traditionally limit the role of the judge have admitted the modification of contract in cases where there was a mandatory discipline for such contracts.

37 In the context of this article, the terms "nullity" and "absolute nullity," are used as synonyms because they refer to the same functional category despite each having different implications depending on the legal tradition of reference, and which remains outside the scope of the present contribution. The same applies for the terms "voidability," "annullability," and "relative nullity." On the category of contractual invalidity, see also infra Section 3.1.

38 See Patrick Selim Atiyah, The Rise and Fall of Freedom of Contract (Oxford: Oxford University Press, 1979) (providing and overview on freedom of contract between 1770 and 1970). 
Mandatory rules refer to statutes, common law principles, or compulsory rules, but not "fundamental principles." 39 The differences have already been highlighted, for instance, in the Draft Common Frame of Reference (DCFR). ${ }^{40}$

The problem of flexibility in the approach of a legal system logically arises after this latter has established that the contract cannot be saved by interpretation or by hetero-integration (another relevant general issue), and - at the same time - cannot be separated from the issue of the interpretation of the specific law which assumes the existence of a conflict. This divergence complicates the path quite a bit. To be more analytic, in order to translate violation of law into nullity, it is first necessary to interpret both the law and the contract, and it has now been warned that these are neither simple operations nor ones that produce linear results. Then, since the law (including mandatory rules) and the contract are two hierarchically ordered sets of rules, it must also be ascertained that the latter (i.e. the contract) cannot be modified to comply to the former (i.e. the mandatory law). The principle of contract preservation implies that this control precedes the declaration of nullity.

In this context, a flexible approach offers a range of solutions to deal with a contract that infringes mandatory rules. ${ }^{41}$

An example of this last approach can be found in different "model laws." 42 For instance, in the UNIDROIT Principles of International Commercial Contracts (PICC), Art. 3.3.1, Contracts Infringing Mandatory Rules, states that where the mandatory rule does not expressly prescribe the effects of an infringement upon a contract, the parties have the right to exercise such remedies under the contract as long as the circumstances are reasonable. ${ }^{43}$ Different criteria in determining what is reasonable must be taken into consideration. ${ }^{44}$ Thus, in the case of infringement

39 The identification of the mandatory rules may indeed be controversial. $C f$. Guido Alpa, "Party Autonomy and Freedom of Contract Today,” Eur. Bus. L. Rev. 21 (2010): 119.

40 Christian Von Bar, Hans Schulte-Nölke, and Eric Clive, Principles, Definitions and Model Rules of European Private Law Draft Common Frame of Reference (DCFR) (München: European Law Publisher, 2009). On fundamental principles, see "Comment B, Article II.-7:301 (Contracts Infringing Fundamental Principles).”

41 Certain flexibility is also known in national laws. For instance, in English law the general rule is that contracts against mandatory rules are unenforceable by the courts. However, in certain circumstances, the courts have discretion to grant a different remedy. See generally McKendrick, Contract Law, 309.

42 Meier, "Illegality," 1887-1907 (analyzing and comparing PICC, PECL and DCFR on illegality). 43 See "Article 3.3.1 (Contracts Infringing Mandatory Rules)."

44 The same article provides a non-exhaustive list of criteria to determine the contractual remedies available, if any. In many cases, more than one of the criteria will be relevant and the decision will involve a weighing of the following criteria: (a) the purpose of the rule infringed; (b) the category of persons for whose protection the rule exists; (c) any sanction that may be imposed under the rule infringed; (d) the seriousness of the infringement; (e) whether one or both 
of a mandatory rule, one or both parties may be granted ordinary remedies available under valid contracts (including the right to performance), or other remedies, such as the right to treat the contract as having no effect-the adaptation of the contract or its termination on terms to be fixed. ${ }^{45}$

Under the banner of flexibility, in the Principles of European Contract Law (PECL) formulated by the Lando Commission, ${ }^{46}$ Art. 15:102 Contracts Infringing Mandatory Rules, states that where the mandatory rule does not expressly prescribe the effects of an infringement upon a contract, the contract may be declared to have full effect, to have some effect, to have no effect, or to be subject to modification. ${ }^{47}$ The decision should be an appropriate and proportional response to the infringement, regarding all relevant circumstances listed in the same article. ${ }^{48}$

Comparable flexibility is codified in the DCFR, Art. II. $-7: 302$, Contracts infringing mandatory rules, where it explains that, in such a case, a degree of discretion is given to the Court to declare the contract valid to avoid the contract with retrospective effect in whole, in part, or to modify the contract or its effects. The decision should be an appropriate and proportional response to the infringement regarding all relevant circumstances specified in the Article itself. ${ }^{49}$

The key to the model laws mentioned is that the remedy must be appropriate and proportional to the infringement. All rules include a non-exhaustive list of factors and circumstances that must be taken into account such as: the purpose of the rule infringed; the category of persons for whose protection the rule exists; any

parties knew or ought to have known of the infringement; (f) whether the performance of the contract necessitates the infringement; and ( $\mathrm{g}$ ) the parties' reasonable expectations.

45 See "Article 3.3.1 (Contracts infringing mandatory rules), Comment n. 5."

46 See Ole Lando et al., The Principles of European Contract Law, Parts III, 1st ed. (The Hague: Kluwer Law International, 2003), 213-221.

47 "Principles of European Contract Law - PECL, Ch. 15: Illegality, Article 15:102 (Contracts Infringing Mandatory Rules).”

48 "PECL, Ch. 15: Illegality, Article 15:102 (3)" (“A decision reached under paragraph (2) must be an appropriate and proportional response to the infringement, having regard to all relevant circumstances, including: (a) the purpose of the rule which has been infringed; (b) the category of persons for whose protection the rule exists; (c) any sanction that may be imposed under the rule infringed; (d) the seriousness of the infringement; (e) whether the infringement was intentional; and (f) the closeness of the relationship between the infringement and the contract").

49 Von Bar, Schulte-Nölke, and Clive, Principles, Definitions and Model Rules. See Art. II.-7:302: (3) ("A decision reached under paragraph (2) should be an appropriate and proportional response to the infringement, having regard to all relevant circumstances, including: (a) the purpose of the rule which has been infringed; (b) the category of persons for whose protection the rule exists; (c) any sanction that may be imposed under the rule infringed; (d) the seriousness of the infringement; (e) whether the infringement was intentional; and (f) the closeness of the relationship between the infringement and the contract”). 
sanction imposed under the rule infringed; the seriousness of the infringement; whether the infringement was intentional; whether one or both parties knew or ought to have known of the infringement; whether the performance of the contract necessitates the infringement; the parties' reasonable expectations; the proximity of the relationship between the infringement and the contract, and so on.

The above approaches' guiding principle is to seek a balanced approach, where flexibility and proportionality may be translated into various remedies to deal with contracts that infringe mandatory rules. The search for an appropriate remedy is not left to a general "justice or fairness or equity" principle - instead, a given set of criteria offers a guide to prevent that more flexibility could lead to the law's unpredictability.

\subsection{A More Rigid Approach}

Generally speaking, those that advocate the rigid approach fundamentally assert that rigidity is linked to predictability and, thus, flexibility in establishing remedies could lead to unpredictable results. Therefore, according to this opinion, any benefits of the flexible approach are outweighed by the potential disruptive impact such elasticity has on legal certainty.

Within the boundaries of a more rigid approach, it could be included the one that - in the case of a contract that infringes mandatory rules - confines the judge to choose between the alternative of whether the contract is either valid or null without allowing him to scale the remedies. ${ }^{50}$

This approach can be found, for instance, in the black letter of the Italian civil code, which was influenced by the German model on the point. In Italian law, the cornerstone of "null contracts" is represented by Art. 1418 c.c. It., which identifies three macro groups of null contracts: i.) when the law establishes it; ${ }^{51}$ ii.) when the contracts are contrary to mandatory rules, unless the law provides otherwise; iii.) when the contracts lack an essential element or are illicit. ${ }^{52}$

50 Per section 1, this article does not aim to address the steps involved to "conform" the contract (in accordance with the principle of preservation of contract), through a process of heterointegration, modification and severability of the contract.

51 The first category is very clear. The legislator specifically regulates numerous cases according to which contracts are expressly null. These instances are called "textual nullity." A classic example is provided by agreements as to future successions; in Italian law, those contracts are expressly considered null (Art. 458 c.c. It.).

52 In Italian law, the third group of null contracts (pursuant to Art. 1418(2) c.c. It.) denotes contracts that are "illicit" or missing an essential element. While the second case is quite easy to understand (e.g. a contract is void for lack of agreement), the contract is illicit when its causa, object, reasons, or condition is illicit (i.e. it is contrary to mandatory rules, public order or good 
The second group is relevant for this work, governed by Art. 1418(1) c.c. It. This rule derives from $\$ 134$ of the German civil code (Bürgerliches Gesetzbuch or BGB) ${ }^{53}$ of 1900 , which states contracts against mandatory rules ${ }^{54}$ are null unless the law provides otherwise. ${ }^{55}$ The Italian model of invalidity was influenced by the German model, which included invalidity via the category of annullability to protect the other party's interest, while nullity was considered to defend the general interest. ${ }^{56}$

This article is not the place for an in-depth examination of the problems or the extensive debate underlying Art. 1418(1) civ. cod. It., but it is important to note that it introduces the category of so-called "virtual nullities," i.e., nullities resulting from the violation of mandatory rules without the legislator expressly declaring such nullity. ${ }^{57}$ Both doctrine and case-law agree that: i.) the contract can be null even when the legislator has not expressly provided for nullity; ii.) when the law "provides otherwise," an express exclusion is not necessary (it is sufficient to infer a different solution by way of interpretation on the basis of the rationale and the purpose of the rule). ${ }^{58}$ Therefore, in order to simplify as much as possible, in the case of infringement of a mandatory rule, if the legislator is silent (i.e., without expressly providing for nullity or exclusion of nullity), everything is left to the interpreter who either affirms or denies nullity based on the purpose and function of the violated

morals). See Giovanni Perlingieri, Negozio illecito e negozio illegale. Una incerta distinzione sul piano degli effetti (Napoli: Edizioni Scientifiche Italiane, 2003) (providing a more detailed analysis of the subject).

53 On § 134 BGB, $c f$. , Häcker, “The Impact of Illegality,” 344.

54 See generally Antonio Gambaro, “Contratto e Regole Dispositive,” Riv. Dir. Civ (2004): 10-11; Horatia Muir Watt and Ruth Sefton-Green, "Fitting the Frame: An Optional Instrument, Party Choice and Mandatory/Default Rules," in European Private Law after the Common Frame of Reference (Cheltenham/Northampton: Edward Elgar, 2010), 211-231.

55 But see Zimmermann, The Law of Obligations, 701 (stating: "it is even argued today that $\S 134$ BGB does not confine the judge to the alternative of all or nothing (i.e., contract either valid or invalid), but opens up the possibility of upholding the contract in a modified form”). As already stated, the idea of preservation of contract is not part of this work.

56 For a brief summary, e.g., Adolfo Di Majo, "La Nullità," in Trattato di diritto privato, ed. Mario Bessone, vol. 8 (Torino: Giappichelli, 2002), 39-472; Paolo Gallo, "Il Contratto," in Trattato di diritto privato (Torino: Giappichelli Editore, 2017); Rodolfo Sacco, "Le invalidità," in Rodolfo Sacco e Giorgio De Nova, Il Contratto, 4th ed. (Torino: Utet Giuridica, 2016), 1455-1544.

57 See generally Gianroberto Villa, Contratto e violazione di norme imperative (Milano: Giuffré, 1993), 4.

58 See generally Raffaele Moschella, "Il negozio contrario a norme imperative" in Legislazione Economica (1978-1979), eds. Gustavo Visentini and Francesco Vassalli, vol. 4 (Milano: Giuffré, 1981), 271-367; Giorgio De Nova, "Il contratto contrario a norme imperative," Riv. Crit. Dir. Priv. (1985), 440 ff.; Villa, Contratto e violazione, 26-276; Antonio Albanese, Violazione di norme imperative e nullità del contratto (Napoli: Jovene, 2003), 125 ff.; Giovanni D'Amico, "Nullità non testuale," in Enciclopedia del diritto, Annali, vol. 4 (Milano: Giuffré, 2011), 798 ff. 
mandatory rules. ${ }^{59}$ The problem is not new; it has been discussed in Roman law, in the ius commune, ${ }^{60}$ and is still an issue common to different legal systems. ${ }^{61}$ The problem of virtual nullity is familiar also in France, where the famous principle pas de nullité sans texte (no nullity without a text), established by the Canonists to limit cases of nullity in certain matters (such as marriage), and the repudiation of nullity from the Ancien Régime is still felt. ${ }^{62}$

In the Italian legal system, scholars and case law have been working for decades to clarify cases in which the violation of mandatory rules leads to the contract's nullity and in which cases it does not. ${ }^{63}$ Various positions have developed over time. ${ }^{64}$ For example: i.) mandatory rules involving nullity should be more compelling than others; ${ }^{65}$ ii.) the purpose of the prohibition distinguishing whether the interest of a social or general nature is at stake, the violation of the rule leads to nullity - if they are rules of a fiscal, currency, police nature accompanied by fines, penalties, there is no nullity (albeit the imposition of a sanction does not in itself exclude that it can accumulate with the nullity of the contract); ${ }^{66}$ iii.) nullity is only applied if it is the only way to fully achieve the purpose of the violated law; ${ }^{67} \mathrm{iv}$.) nullity, depending on whether the prohibition is addressed to both parties or one of

59 See De Nova, "Il contratto contrario a norme imperative," 453; Villa, Contratto e violazione, 78 ff.

60 Gallo, Il Contratto, 846.

61 In English law, when dealing with statutory illegality, in addition to express prohibition, there is implied prohibition. See Sir Jack Beatson, John Cartwright, and Andrew Burrows, Anson's Law of Contract, 30th ed. (Oxford: Oxford University Press, 2016) (affirming “ ... in the absence of a clear implication [...] Courts are cautious in construing a statute in this way, in part because "so much of commercial life is governed by regulations of one sort or another; which may be easily be broken without wicked intent”).

62 See David Deroussin. "Pas de nullité sans texte. Éléments pour une archéologie d'une directive," Revue des contrats 1 (2018), 145; Gallo, Il Contratto, 846.

63 Cf., Gianroberto Villa, "Contratto illecito ed irripetibilità della prestazione. Un'analisi economica," in Quadrimestre, 30th ed. (Milano: Giuffrè, 1992), 19 (providing a detailed analysis on the topic).

64 This is just a very brief summary. See generally, Fabrizio Di Marzio, La nullità del contratto (Padova: CEDAM, 2008), 435 ff.; Arturo Maniaci, "Lo scenario delle c.d. nullità speciali," in Annales De Droit Privé (Milano: Giuffrè, 2011), 387-408 (both discussing in detail the various legal theories).

65 To this end, the rank of the violated standard may take on importance. See Villa, Contratto $e$ violazione, $112 \mathrm{ff}$. (discussing the topic in futher detail).

66 See Francesco Ferrara, Teoria del negozio illecito nel diritto civile italiano (Milano: Società editrice libraria, 1914), $23 \mathrm{ff}$. (indicating the purpose of the ban as a criterion for identifying mandatory rules).

67 Some authors have proposed the "minimum means" criterion, according to which nullity is to be "excluded if the requirement pursued by the legislator through the provision of the specific sanction (civil, administrative or criminal) is fully achieved by their imposition, whereas it must be 
them; ${ }^{68}$ v.) the "structural criterion" used in the case law. ${ }^{69}$ According to the last approach, only the violation of mandatory rules concerning the contract's validity can determine a contract's nullity for conflict with mandatory rules. Whereas the violation of binding supplementary contract rules concerns the behavior of the contracting parties, if they meet certain conditions, their violation may give rise to pre-contractual liability (with compensatory consequences, if they occur before or during the conclusion of the contract) or contractual liability, and eventually lead to the termination. ${ }^{70}$ The distinction between rules of validity concerning genetic defects of the contractual relationship and rules relating to the contractual relationship's performance has the effect of narrowing the scope of the category of nullity further than that which supporters of "pannullism" would like to assign to it. Thus, it is appropriate to highlight that there is a trend in Italy to move away from the civil code categories of nullity/annullability and towards an atomistic model of nullity, under which nullity may assume various forms (e.g., the so-called special nullities, relative nullities, nullities of protection, and so on). ${ }^{71}$ The term "special nullities" reflects their collocation in "special" statutes and mainly their "special" discipline. They intend to protect special interests or, better yet, the interests of certain categories of contracting parties. ${ }^{72}$ Often, special nullities are represented by the so-called nullity of "protection."73 These nullities, as an exception to the provisions of Art. 1421 c.c. It may be invoked only by the party protected by the law, i.e., the one in whose favor the nullity operates. This is why nullity may be requested only by the party worthy of protection, who could also request that the contract be "validated." This form of nullity is presupposed to be in the general interest to protect the weaker party in the contractual relationship, ${ }^{74}$ which again implies

admitted otherwise." See De Nova, "Il contratto contrario a norme imperative," 446. Cf. Villa, Contratto e violazione, $130 \mathrm{ff}$.

68 See De Nova, "Il contratto contrario a norme imperative," $446 \mathrm{ff}$.

69 For Italian readers, a complete overview on invalidity of contracts in the Italian legal system is offered by Gallo, Il Contratto, 833 ff. See also Sacco, "Le Invalidità,” 1455 ff.

70 From Cass. sez. un., 19 dicembre 2007, n. 26724/2007, Giustizia Civile Massimario 2007, 12 (It.) onwards.

71 See e.g., Aurelio Gentili, "Nullità, annullabilità, inefficacia (nella prospettiva del diritto europeo)," Contratti (2003): 200-205; Claudio Scognamiglio, "Regole di validità e di comportamento: i principi ed i rimedi," Europa e Diritto Privato (2008): 623.

72 Gallo, Il Contratto, 833.

73 For instance, the Italian Consumer Code (Legislative Decree No. 206 of 6 September 2005) has codified the nullity of "protection" in Art. 36 to protect the consumer. Among Italian scholars: Aurelio Gentili, “La 'nullità di protezione'," Europa e Diritto Privato (2011): 77-119.

74 The special nullities are intended to protect the special interests or, better, the interests of certain categories of contracting parties. See generally Gallo, Il contratto, 833. 
adopting a policy substratum opposed to the laissez faire approach (which was the substratum of the nullity/annullability dichotomy). This development considerably enlarges the area of nullity. These nullities have become increasingly used by the legislator in special statutes, ${ }^{75}$ and recently have been promoted even by the 2019 bill to amend the Civil Code. Indeed, the bill's technical report would favor an extension of the mechanism of nullity of protection such that it would almost become an institution of general application. However, this important nullity of protection has not taken root in "virtual nullity" pursuant to Art. 1418(1) c.c. It.; Italian scholars still debate its admissibility, although the European trend seems to suggest its adoption. $^{76}$

Despite the legal framework for invalidity being complex (it cannot be fully covered here), a final note to highlight is that the distinction between nullity ${ }^{77}$ and annullability may be found in the Italian legal system. ${ }^{78}$ However, in the context of contracts that violate mandatory rules (Art. 1418(1) c.c. It.), annullability does not play a role. Only nullity may be declared, with all its effects and peculiarities - the action for declaration of nullity may be asserted by any interested party; it can also be declared, sua sponte ("ex officio"), by the court. Moreover, a null contract cannot be validated unless provided by law, and the action of nullity is not subject to the law of limitation. The declaration of nullity affects the contract from its onset as if the contract never existed. ${ }^{79}$

Comparatively, in Austria, despite the rigid wording of Article 879(1) of the Civil Code of 1811 (Allgemeines Bürgerliches Gesetzbuch or ABGB), which states “[a]

75 See arts.117 and 127 T.U.B. (D.lgs No. 385 of 1 Sept. 1993); Art. 6, Law No. 192 of 18 June 1998; Art. 36 Consumer Code.

76 For a case of special virtual nullity of an agreement in family matters, which can only be invoked by the weaker spouse, see Cass., 1 dicembre 2000, n. 15349, Giust. civ. 2001, I, 1592 (It.). 77 See supra at note 7.

78 An English translation of the Italian civil code is offered by Mario Beltramo, Giovanni E. Longo, and John H. Merryman, trans., The Italian Civil Code and Complementary Legislation, New revised and updated ed. by Mario Beltramo (Dobbs Ferry: Oceana Publication, 1991).

79 In this article, is not possible to analyze the characteristics of the two different forms of invalidity. Rather, for the purposes of the present contribution, it is sufficient to remember that, according to the definition given by the Italian Civil Code, in case of annullability/voidability: (1) the contract is effective until the voidability is legally ascertained; (2) the voidability can only be invoked by the interested party; (3) it cannot be ascertained by the judge ex officio; (4) it can be confirmed by the parties; and (5) the action is limited within five years. While the boundaries between the two forms of invalidity (i.e. nullity and annullability) appear clear-cut in the black letter of the code, as authoritative doctrine has highlighted, they are much more blurred. Rodolfo Sacco, "Nullità ed annullabilità (Diritto Civile)," Novissimo Digesto Italiano 11 (1965): 455; Id., "Le invalidità,” Trattato di diritto privato. Obbligazioni e contratti 10 (2002): 607; Id., "Le invalidità," $1484 \mathrm{ff}$. 
contract which violates a legal prohibition or public morality is null and void," 80 the courts make a distinction between an absolute nullity and a relative nullity which depends on its assertion. If the statute's purpose is merely to protect the other party and does not refer to public interest, it is the party's responsibility to request the declaration of (relative) nullity. ${ }^{81}$ Contracts that breach statutes seeking to safeguard the community's general interests are null and void, and no declaration of avoidance is necessary. ${ }^{82}$ A similar approach appears in the 1992 Civil Code of the Netherlands (Burgerlijk Weboek [or BW]). In particular, according to Art. 3:40(2) BW, a juridical act that violates a mandatory law's statutory provision is null and void. ${ }^{83}$ However, suppose this statutory provision merely intends to protect one of the parties to a more-sided (multilateral) legal act. In that case, such a legal act is voidable, provided that it is in line with the underlying principle of the violated statutory provision. In French law, the classical theory viewing absolute and relative nullity as opposites was recently codified by way of the 2016 reform of the French Civil Code. ${ }^{84}$ Since the beginning of the 20th century, this theory has been strongly criticized. Such criticism derives from the doctrine establishing an objective conception which claims that because nullity is the sanction of a legal norm - is from the nature of the latter - that the purpose and the nullity regime must be inferred. ${ }^{85}$

Even if the pivot on which the distinction between absolute nullity and relative nullity (i.e., public interests and private interests) has lost its driving force in modern welfare legal systems since the end of the laissez faire economy, this distinction is still present in civil law doctrine (albeit not without causing a degree of confusion). The epochal passage between a laissez faire model and one that seeks to regulate

80 Willibald Posch, "Austria” in International Encyclopedia of Law: Contracts, ed. Jacques H. Herbots (Alphen aan den Rijn, The Netherlands: Kluwer Law International, 2016), 108.

81 Ibidem.

82 Ibidem, (noting, in case of absolute nullity, everyone has the right to substantiate the nullity. This right is not subject to a period of limitation. Comparatively, in case of relative nullity, the party suffering detriment from the illegal contract must invoke the violation of the legal rule to make it clear that the contact is null).

83 See “Art. 3:40” Burgerlijk Weboek, accessed May 13, 2020. On nullity, see J. Hijma, “The Concept of Nullity," in Core Concepts in the Dutch Civil Code: Continuously in Motion, eds. C.G. Breedveld-de Voogd et al., 1st ed. (Wolters Kluwer Netherland B.V., 2016), 17-37.

84 Ordonnance no 2016-131 du 10 février 2016 portant réforme du droit des contrats, du régime général et de la preuve des obligations, JORF no 0035 of 11 February 2016. The Ordonnance was translated by John Cartwright, Bénédicte Fauvarque-Cosson and Simon Whittaker: http://www. textes.justice.gouv.fr/art_pix/THE-LAW-OF-CONTRACT-2-5-16.pdf.

85 See Renè Japiot, Des nullités en matière d'actes juridiques. Essai d'une théorie nouvelle, thèse de doctorat (Paris: Dijon 1909); Eugène Gaudemet, Théorie générale des obligations: Réimpression de l'édition de 1937 (Paris: Dalloz, 2004), 146. For details on the French law on nullity: Yves Picod, “Nullité,” in Encyclopédie de droit civil (Paris: Dalloz, 2019) (2014). 
and govern the contract presupposes a broadening of the notion of public or general interest, which tends to be infinite. In this inflation, many corporate sector interests (which may easily be considered public interests) and some overprotection requirements are included in the public interest. However, since the category of nullity (with all its automatic effects) has been conceived as a sanction against abnormal contractual conduct, it is imaginable that its consequences in its new dimension are disproportionate to the seriousness of the damage caused to the public interest. ${ }^{86}$ Responding to the infringement of mandatory rules with the total demolition of the contract (i.e., absolute nullity) might again mean using the ax even when the right tool may be the chisel.

\section{In Pari Delicto: A Rule Worth Reconsidering}

The legal framework constituted by the (relative) equivalence between illegal and void contracts, as well as by the two Latin maxims ex turpi causa non oritur actio or in pari delicto potior est conditio defendentis ${ }^{87}$ (which describe the specific effects of "bilateral" illegality), is well-known. Surprisingly, these rules, which embodied the original common core of the WTL, could still govern this area of law in different legal systems. ${ }^{88}$

The doctrine of illegality incorporated in the maxims mentioned above has not "aged" well. ${ }^{89}$ Furthermore, it is convenient to observe that the terms turpis causa and delictum associate contracts with a criminal or shameful element, and not with everyday life.

As a very general rule, the obligations that have been performed under a null and void contract must be returned per the rules concerning the restitution of

86 Häcker, “The Impact of Illegality,” 348-349.

87 This Latin maxim denotes the principle that, when the parties are equally at fault, the defendant's position is more compelling.

88 The criticisms of the doctrine of illegality are certainly not new. See e.g., J. K. Grodecki, "In Pari Delicto Potior Est Conditio Defendentis," L.Q. Rev. 71 (1955): 254-268; Stephen M. Waddams, The Law of Contracts (Toronto, Canada: The Carswell Company Ltd., 1977), 562-586; Michael Philip Furmston, "The Analysis of Illegal Contracts," University of Toronto Law Journal 16, no. 2 (1966): 267; Schwartz, "Law Reform Commission," 83-267.

89 E.g., Mitchell McInnes, "Illegality and Canadian Private Law: Hall v Hebert's Legacy," in Illegality After Patel v. Mirza, eds. Sarah Green and Alan Bogg (Oxford: Hart Publishing, 2018) (stating, "The private law doctrine of illegality has not aged well. Most of the foundational cases date to the eighteenth century. At a time when Parliament passed relatively little legislation, it made some sense to void a transaction that was created or performed in contravention of a statute. However, as the regulatory state reached ever further, into virtually every aspect of life, that proposition became indefensible"). 
payments not due. However, in the case of illegal contracts, illegality has constituted a general bar to a claim for restitution. The European Court of Justice ${ }^{90}$ has recently recognized the principle stating that no one should profit from his own unlawful conduct is a common principle in the Member States' legal systems. This belief is not limited to Europe, ${ }^{91}$ and, although with some differences, it has been a common core of most Western Legal Traditions. The soluti retentio has been codified - albeit in different ways - by various legal systems. For instance, this approach is used by the Swiss, ${ }^{92}$ Austrian, ${ }^{93}$ German, ${ }^{94}$ and other legal systems. ${ }^{95}$ The rule is also very well known in common law countries where the words of Lord Mansfield in Holman $v$. Johnson (1775) have been very frequently quoted: "no court will lend its aid a man who founds his cause of action upon an immoral or illegal contract." 96 Another eloquent statement of this view is the one according to which "no polluted hand shall touch the pure fountains of justice." 97

The previously mentioned Latin maxims have made their way into the common law and have been "translated" into the so-called doctrine of illegality. This doctrine was built on them over two centuries and, over time, became a defense

90 One might recall, in particular, Courage Ltd v. Crehan (decision C-453/99 of 20 September 2001 of the European Court of Justice): "Under a principle which is recognised in most of the legal systems of the Member States and which the Court has applied in the past (see Case 39/72, Commission v Italy,1973, ECR 101, paragraph 10), a litigant should not profit from his own unlawful conduct, where this is proven".

91 See infra Section 4.2 on the United Stated and Australian legal systems.

92 "Swiss Civil Code (Part Five: The Code of Obligations), Art. 66," Federal Act on the Amendment of the Swiss Civil Code: "No right to restitution exists in respect of anything given with a view to producing an unlawful or immoral outcome."

93 According to the first line of ABGB ( $§ 1174$ ) there is no restitution for what an individual has knowingly given for the performance of something impossible or illegal.

94 The German BGB ( $\S 817$ ) provides that, "If the purpose of performance was determined in such a way that that the recipient, in accepting it, was violating a statutory prohibition or public policy, then the recipient is obliged to make restitution. A claim for return is excluded if the person who rendered performance was likewise guilty of such a breach, unless the performance consisted in entering into an obligation; restitution may not be demanded of any performance rendered in fulfilment of such an obligation." "German Civil Code BGB," www.gbmjv.de (Bundesministerium der Justiz und für Verbraucherschuzt), accessed May 13, 2020, https://www.gesetze-im-internet. de/englisch_bgb/index.html.

95 In Greece, although illegal contracts are null and void, there is a highly criticized rule preventing restitution for immoral contracts (Art. 907 c.c. Gr.). The rule against restitution is also known in Cyprus. See Natalia Charalampidou, "Cyprus" in International Encyclopedia of Law: Contracts, ed. Jacques H. Herbots (Alphen aan den Rijn, The Netherlands: Kluwer Law International, 2016): 53 (stating the application of the rule in pari delicto in a case related to a contract for illegal diamond trade).

96 Holman v. Johnson, 1775, 1 Cowp 341.

97 Collins v. Blantern, 1767, 2 Wils. K.B. 347, 350, 95 Eng. Rep. 850, 852. 
used, on the one hand, to freeze the action of those who act to require the performance of an illegal/void contract and, on the other hand, to paralyze the action for restitution of those who, in pari delicto, had already performed the contract. Not even an action for damages could be brought and therefore common law remedies were useless. If more elasticity developed for the first case, it took more than two centuries to remove the bar for restitution.

Those words highlight some of the policy reasons that even today should justify the survival of the rule against restitution, ${ }^{98}$ such as maintaining the integrity of the legal system; furthering the purpose of the rule which the claimant's illegal behavior has infringed; the need to prevent the claimant profiting from his or her own wrong; deterrence; ${ }^{99}$ consistency; punishment and others. ${ }^{100}$

In Italy, the rule against restitution is codified under Art. 2035 c.c. It., according to which if a contract is against good morals (a narrower subset of illegal contracts) and the parties involved are in pari causa turpitudinis, restitution is unavailable. It is important to highlight that the Italian civil code limits this approach to immoral contracts and not to other illegal contracts. The historical origins in Roman law sanctioning contracts contra bonos mores $^{101}$ are evident, ${ }^{102}$ and this principle has been codified mostly in European civil codes that contain general clauses stating that contracts against public policy or good morals are null and void. ${ }^{103}$ Whereas public policy ${ }^{104}$ and immorality stand on the same foot in common law countries

98 See Ian Ayres and Gregory Klass, Studies in Contract Law (University Casebook Series) (St. Paul, MN: Foundation Press, 2017) (suggesting that another reason might be to encourage opportunism in these situations, or to undermine honor among thieves).

99 Cf., Kostritsky, "Illegal Contracts and Efficient Deterrence," 115 (suggesting efficient deterrence as an alternative method of deciding cases involving illegal contracts).

100 See English Law Commission, Consultative Report, "The Illegality Defence” (The Law Commission, 2009).

101 Literally "against good morals."

102 See Zimmermann, The Law of Obligations, 706 ff.; Theo Mayer-Maly, "The Boni Mores," THRHR 50 (1987): 60 (generally discussing the topic from a historical and comparative perspective).

103 The general rule concerning the invalidity of immoral transactions has its roots in Roman law; it later appeared in different legislation. In Germany, law concerning the invalidity of immoral transactions was first seen in 1578-in the Frankurt Reformation-and subsequently in numerous city and state codes. See F. Dorn, "Illegality and Immorality," in The Oxford International Encyclopedia of Legal History, ed. S. N. Katz, trans. J.M. Baboukis, vol. 3 (Oxford: Oxford University Press, 2009), 204.

104 An often-quoted description of public policy, which does not conceal the difficultly in defining it, is the one in Richardson v. Mellish, 1824, 2 Bing. 229, 252, 130 Eng. Rep. 294, 303: "a very unruly horse, and when once you get astride it you never know where it will carry you. It may lead you from the sound law. It is never argued at all but when other points fail." See Beatson, Cartwright, and Burrows, Anson's Law of Contract, 415 (discussing the evolution of public policy in 
(even if the majority of the case law on "immorality" relates to sexual immorality), ${ }^{105}$ in some civil law countries (including Italy), these two separate concepts (namely public order and good morals) may lead to different effects. ${ }^{106}$ In the Italian legal system, both contracts against public order or good morals are void. However, as an exemption to the general effect of void contracts (i.e., what was received must be restored), ${ }^{107}$ when the contract is against good morals, and the parties are in pari delicto, ${ }^{108}$ restitution is unavailable. ${ }^{109}$

Italian law is not alone in this approach. For instance, although not codified, French law ${ }^{110}$ distinguishes between "contrats immoraux"111 and those

common law: "By the beginning of the nineteenth century the lack of definition and consequent uncertainty of the concept led to judicial statements against the extension of public policy which was described as 'a very unruly horse.' [...] The effect of the nineteenth-century emphasis on freedom of contract was reluctance to interfere with a contract on the ground of public policy. [...] By the second half of the twentieth century, however, the positive function of the Courts in matters of public policy was increasingly recognized. [...]. Most recently it has been said that, apart from criminal act, ex turpi causa principle is concern only with claims founded on dishonesty or corruption, some anomalous categories of misconduct (such as prostitution) which without themselves being criminal are contrary to public policy and involve criminal liability on the part of secondary parties, and the infringement of statutory rules enacted for protection of the public interest and attracting civil sanctions of a penal character"). See also Percy H. Winfield, "Public Policy in the English Common Law." Harvard Law Review 42, no. 1 (1928): 76; Glanville L. Williams, "The Legal Effect of Illegal Contracts.” The Cambridge Law Journal 8, no. 1(1942); Grodecki, "In Pari Delicto," 254; J. Sumption, "Reflections on the Law of Illegality," Restitution Law Review 20, (2012): 1. See generally on the topic, Richard A. Buckley, Illegality and Public Policy, 4th ed. (London: Sweet \& Maxwell, 2017) (discussing illegality and public policy in the context of contract).

105 See Beatson, Cartwright, and Burrows, Anson's Law of Contract, 424. For instance, in India, for the purpose of contract law, immorality has been confined, by the Supreme Court, to concepts of sexual immorality, see Bhadbhade, "India,".

106 See Häcker, “The Impact of Illegality,” 340 ff. (discussing in detail illegality and immorality in civil law systems).

107 In accordance with the rule concerning restitution of payments not due (Art. 2033 c.c. It).

108 The action for undue payment is admissible if the 'immorality' is attributed only to the person who received the performance.

109 See Francesco Paolo Patti, "The Denial of Restitution Under Italian Law: A Perspective on Patel v. Mirza," European Review of Private Law 26, no. 2 (2018): 255-264 (discussing Patel v. Mirza from an Italian perspective).

110 See Giulia Terlizzi, "Erosione e scomparsa della clausola dei 'buoni costumi' come limite all'autonomia contrattuale," Persona e Mercato 1 (2018): 135-144; Giulia Terlizzi, Buon costume e ordine pubblico (in diritto comparato), Dig. disc. priv. Sez. civ., Aggiornamento (Torino, 2016), 1526.

111 It means "immoral contracts." 
that were merely "illicit"; restitution was only unavailable in the first case. ${ }^{112}$ French legal scholars have explained that the law in action was not "rigid" on the point, and the judges had maintained a certain margin of discretion to assess whether or not restitution was appropriate under the circumstances of the specific case. ${ }^{113}$ However, in France, through the Reform of the French Civil Code in $2016,{ }^{114}$ the Legislator opted for the elimination of any reference to good morals as an effect of its progressive assimilation to public order, ${ }^{115}$ which, as evidenced in the text of the Ordonnance's presentation, ${ }^{116}$ was described as obsolete with respect to the evolution of society and case law had progressively abandoned it. ${ }^{117}$

In Italian law, the leading doctrine ${ }^{118}$ defines good morals as the set of ethical principles shared by the societal majority would perceive an act contrary to them as immoral and shameful. Another authoritative doctrine ${ }^{119}$ emphasizes how good

112 Samuel Fulli-Lemaire, “Les Restitutions Consécutives à l'Annulation Du Contrat Illicite Brèves Réflexions Sur Le Droit Français Réformé Des Contrats à Partir De l'Arrêt Patel c. Mirza (Restitution Following the Annulment of an Illegal Contract: Brief Observations on the New French Law of Contract on the Basis of Patel v. Mirza)," European Review of Private Law 26, no. 2 (2018): 265-271 (discussing Patel v. Mirza from a French perspective).

113 See Fulli-Lemaire, "Les Restitutions," 265-268 (highlighting “Derrière l'apparence d'une règle rigide exprimée par le célèbre adage Nemo auditur, les considérations d'opportunité semblent jouer un rôle décisif dans la construction de la jurisprudence." [Behind the appearance of a rigid rule expressed by the famous adage Nemo auditur, considerations of expediency seem to play a decisive role in the construction of jurisprudence]).

114 See supra at note 84.

115 See Terlizzi, "Erosione e scomparsa," 135-144; Attilio Guarneri, "La scomparsa delle "bonnes moeurs" dal diritto contrattuale francese," Nuova giur. civ. comm 33, no. 3 (2017): 404-414; Terlizzi, Buon costume, 15-26.

116 Report of the President of the Republic on Ordinance No. 2016-131 of 10 Feb. 2016 reforming the law of contracts, the general regime and the proof of obligations, JORF No. 0035 of 11 Feb. 2016, Text No. 25, Chapter 1: Introductory Provisions.

117 The French Government stated that it removed "good morals" - despite a preliminary article of the Civil Code remaining in force (i.e. Article 6 c.c. Fr: On ne peut déroger, par des conventions particulières, aux lois qui intéressent l'ordre public et les bonnes moeurs [There can be no derogation, by means of special agreements, from the laws concerning public order and morality]) - and that a contract cannot derogate from the laws concerning public order and good morals. Consequently, given the legislator's silence on this point, the future of this rule on lack of restitution is unknown, although the absence of reference in the code might suggest its repeal, at least in its previous form.

118 Vincenzo Roppo, "Il Contratto," in Trattato di diritto privato, eds. Giovanni Iudica and Paolo Zatti, 2nd ed. (Milano: Giuffrè, 2011), 387. See also Giovanni Battista Ferri, "Buon costume (dir. civ.)," in Enciclopedia giuridica Treccani 5 (Treccani 1988).

119 Rodolfo Sacco, "Il contenuto del contratto", in Rodolfo Sacco and Giorgio De Nova, Il Contratto, 4th ed. (Torino: Utet Giuridica, 2016), 1003. 
morals constitute a body of non-formalized pre-juridical deontological rules, e.g., the trade in sexual services, adopting an opinion for profit, etc. Accordingly, the difference between the two is that public order expresses the legislator's political choices, ${ }^{120}$ while the principles of good morals are extra-legal since they flow from society without the mediation of political authority. ${ }^{121}$

The idea of good morals has not gone without criticism. Indeed, pluralistic society could express various and contradictory ethical principles. Moreover, the legislative inflation has hardly left room for the development of unwritten law, or, more specifically, good morals. Almost all social prohibitions (i.e., behaviors that provoke social disapproval) have become legal prohibitions, and an important role has also been played by the development of fundamental rights (such as dignity or solidarity) in the control of a contract's content. ${ }^{122}$ Thus, the scope of good morals has undoubtedly eroded. ${ }^{123}$

The rule against restitution is highly criticized. ${ }^{124}$ The rationale according to which the rule should serve the policy reason of willingness to conform to people's behaviors does not justify its survival and does not appear to rationalize the

120 The notion of public order includes all the political, social, and economic principles which are the basis of the legal system. See Roppo, "Il Contratto," 384. See also Sacco, "Il contenuto del contratto," 1020 (discussing in detail the Italian concept of public order); Attilio Guarneri, L'ordine pubblico e il sistema delle fonti del diritto civile (Padova: CEDAM, 1974); Stefano Rodotà, "Ordine pubblico o buon costume?," Giur. di mer 1, (1970): 104-105; Pietro Perlingieri, "L'incidenza dell'interesse pubblico sulla negoziazione privata,” Rassegna di diritto civile 4 (1986): 433.

121 Roppo, "Il Contratto," 387.

122 It is not surprising that good morals still have an important role in different traditions. For example, in China, the Civil Code of the People's Republic of China (as adopted at the 3rd Session of the 13th National People's Congress of the People's Republic of China on May 28, 2020, which shall come into force on January 1, 2021) devotes some articles to good morals (namely, arts. 8, 10, 143, 153).

123 Giulia Terlizzi, Dal buon costume alla dignità della persona: percorsi di una clausola generale (Napoli: Edizioni Scientifiche Italiane, 2013).

124 See Pietro Rescigno, "In pari causa turpitudinis," Riv. dir. Civ. 1 (1966): 1-57; Villa, "Contratto illecito ed irripetibilità," 19; Id., "Contratto e violazione”; Daniele Maffeis, Contratti illeciti o immorali e restituzioni (Milano: Giuffrè, 1999); Fulvio Gigliotti, Prestazione contraria al buon costume: Art. 2035 (Milano: Giuffrè, 2015); Elena Bargelli, Ripetizione d'indebito (Torino: Utet Giuridica, 2014); Gianmaria Baraggioli, "I rimedi restitutori: spunti di riflessione tra problemi etici ed economici," in Contratto e Impresa: Dialoghi con la giurisprudenza civile e commerciale, ed. Francesco Galgano (Padova: CEDAM, 2013), 674-687; Loredana Tullio, Le prestazioni indebite di fare tra nullità e irripetibilità (Napoli: Edizioni scientifiche italiane, 2013); Andrea Nicolussi, "Le restituzioni de iure condendo," Eur. e dir. priv. (2012): 783-811; Gallo, "Ripetizione dell'indebito," 880; Elena Bargelli, "Sinallagma rovesciato e ripetizione dell'indebito. L'impossibilità della restitutio in integrum nella prassi giurisprudenziale,” Riv. dir. civ. 1 (2008): 87. 
mechanical correlation between immoral contract and lack of restitution. ${ }^{125}$ Italian doctrines have pointed out that Art. 2035 c.c. It. could lead to unjust results and have reproached the rule as a general principle to apply in every case. ${ }^{126}$ Judges also appear reluctant to apply the rule. As a result, in the last few decades, a scanty number of cases have involved its application. However, it is also true that a recent Italian Supreme Court decision ${ }^{127}$ points out how this approach is still "alive" today. ${ }^{128}$ Once again, the policy reasons under this rule are always referred to at a totally abstract level. It is seldom understandable how they are applied in individual cases, especially when the courts ultimately refer to the above-mentioned Latin maxims without further explanation or open reference to any policy considerations.

\subsection{An Inflexible Approach}

In 2018, the Italian Court of Civil Cassation ${ }^{129}$ applied the Latin maxim in pari causa turpitudinis melior est condicio possidentis when it rejected the request for restitution of the sum of Euro 20,650.84 paid by a father to the defendant as remuneration for the promise of a job for his daughter at a bank, where the defendant represented to have some connections. In support of the claim, the father submitted that he had filed a police report against the defendant for crimes of fraud and boasting credit (which resulted in an acquittal due to running of the statute of limitations), as his daughter had not been hired following the agreement.

Although the judge primae curae (first instance) rejected the claim for lack of evidence, the Court of Appeals of Naples, in the reform of the Court's decision, condemned the opposing party and ordered the sum returned to the father. According to the Court of Appeals, in the case in question, the soluti retentio under Art. 2035 c.c. It. was inappropriate. Instead, the restitution rules for payments not due (Art. 2033 c.c. It.) were applicable since the payment had violated mandatory rules and not only of good morals. Finally, the Court of Cassation ${ }^{130}$ ruled in favor of applying the soluti retentio rule. The Court of Cassation stated that the agreement

125 For a different interpretation of Art. 2035 c.c. It., see Donato Carusi, Le obbligazioni nascenti dalla legge (Napoli: Edizioni scientifiche italiane, 2004), 292.

126 See Patti, “The Denial of Restitution,” 255, 257, 262 (providing references in English to Italian authors and their view on the in pari turpitudinis Latin maxim).

127 Cass., 3 aprile 2018, n. 8169, Foro it. 2018, 10, I, 3228 (It.).

128 See, Cerchia, "Alcune riflessioni," $377 \mathrm{ff}$.

129 Cass., 3 aprile 2018, n. 8169, Foro it. 2018, 10, I, 3228 (It.).

130 For English readers, information on the functioning of the Court of Cassation is available at http://www.cortedicassazione.it/corte-di-cassazione/it/funzioni_corte.page. 
was certainly contrary to mandatory rules, but it was also against boni mores, since paying money in exchange for employment is generally contrary to the commonly accepted concept of good morals. ${ }^{131}$

The Court of Cassation explained that the concept of contract against good morals also includes (additional to those that infringe the rules of sexual decency and decency in general) contracts against the principles and ethical standards of the collective conscience. These contracts are raised to the level of social morality, at a given time and context. The Court of Cassation further explained that since the simultaneous violation of both public order and good morals constitutes a greater offense, they should treat it as an act which is only contrary to good morals. The Court of Cassation additionally specified that, according to the doctrine and the majority of case law, Art. 2035 c.c. It. is applicable when a single contract violates several rules and when one of the violations is also contrary to good morals. ${ }^{132}$ To be clearer, a contract that is void both for infringing mandatory rules and for being against good morals entails the application of Art. 2035 c.c. It. ${ }^{133}$

The Italian Supreme Court appears to have mechanically applied the equation "immoral contract equals lack of restitution" without reference to any considerations or policy reasons. This appears even more true in the context of a previous decision where the Court ${ }^{134}$ affirmed, even in an obiter dictum, that the soluti retentio rule is directly established in the Latin maxims in pari causa turpitudinis melior est conditio possidentis and nemo auditur suam turpitudinem allegans without indication to any other rationale.

Only a few years ago, in 2010, the Italian Supreme Court, although Criminal Section, in a very similar case, in which a father had paid a sum of money in exchange for a false promise to hire his daughter, decided that it was a matter of public policy and application of Art. 2033 c.c. It, by allowing restitution. ${ }^{135}$ Perhaps the Court was pushed to greater attention by weighing the different interests at stake. However, the contradictory output of these two decisions could also undermine the

131 In line with Cass., 18 giugno 1987, n. 5371, Giust. civ. 1988, I, 197 (It.) following the reasoning of Cass., sez. un., 7 luglio 1981, n. 4414, Foro it. 1982, I, 1679 (It.).

132 See contra Sacco, "Il contenuto del contratto", 1103, and, in case law, Cass., 18 giugno 1987, n. 5371/1987, Giust. civ. 1988, I, 197 (It.) and Cass., sez. un., 7 luglio 1981, n. 4414, Foro it. 1982, I, 1679 (It.).

133 Cass., 27 ottobre 2017, n. 25631, Giustizia Civile Massimario 2018 (It.). See also Cass., 18 giugno 1987, n. 5371/1987, Giust. civ. 1988, I, 197 (It.); Cass., 7 luglio 1981, n. 4414/1981, Foro it. 1982, I, 1679 (It.).

134 Cass., 27 ottobre 2017, n. 25631, Giustizia Civile Massimario 2018 (It.) (also explaining that what is significant is preventing the plaintiff from bringing the circumstances of an immoral and shameful agreement before the court in order to obtain a valid title to justify his claim).

135 Cass., sezione penale, n. 35352, 17 settembre 2010. 
idea that a rigid approach undoubtedly leads to predictability of jurisprudential outcomes, at least in some legal systems, such as the Italian one.

It seems that the Italian Supreme Court might not be satisfied by a formal approach capable of producing results which may appear arbitrary, unjust or disproportionate. An automatic application rather than an open reasoning related to the policy considerations related to the application of Art. 2035 c.c. It has left the reader with a sense of axiological disorientation. ${ }^{136}$

What seems most likely is that the principle of proportionality has been forgotten to be replaced by a search for the greatest possible deterrent to illegal conduct. $^{137}$

\subsection{Developments in Favor of Flexibility}

A year and a half before the above-mentioned Italian Court of Cassation, the United Kingdom Supreme Court remodeled the doctrine of illegality in contract law with the well-known case, Patel v. Mirza. ${ }^{138}$ This case has been described as one of the most significant judgments in the area of English private law in recent years, ${ }^{139}$ as the UKSC decided in favor of a restitution award for unjust enrichment despite the source being an illegal contract: the ancient rule that states illegality is the absolute bar for the action of restitution has been definitively removed. ${ }^{140}$

The facts of the case are quite simple. Patel had paid Mirza the sum of $£ 620,000$. The payment was made on the basis of the agreement that Mirza would

136 If it is obvious that common law judges historically have a good familiarity with discretionary choices, civil law judges also have these skills, albeit in different legal contexts.

137 See Cerchia, "Alcune riflessioni," $377 \mathrm{ff}$.

138 Patel v. Mirza, 2016, UKSC 42. See e.g., Andrew Burrows, "Illegality after Patel v Mirza," Current Legal Problems 70 (2017): 55-71; Sarah Green and Alan Bogg (eds.), Illegality After Patel v. Mirza (Oxford: Hart Publishing, 2018); James Goudkamp, “The End of an Era? Illegality in Private Law in the Supreme Court," Law Quarterly Review 133 (2017): 14-20; Anthony Grabiner, "Illegality and restitution explained by the supreme court," The Cambridge Law Journal 76 (2017): 18; Ernest Lim, "Ex Turpi Causa: Reformation not Revolution: Reformation not Revolution," The Modern Law Review 80 (2017): 927. See also Patti, “The Denial of Restitution," 255-263 (discussing Patel v. Mirza from an Italian viewpoint, including a more in-depth analysis of Art. 2035 c.c. It).

139 Sarah Green and Alan Bogg, Illegality After Patel v. Mirza (Oxford: Hart Publishing, 2018), 2. 140 These rules had some exceptions. The most important were when the parties were not in pari delicto and when the claimant withdrew from the transaction during the locus poenitentiae (a space or time for repentance). See generally Andrew Burrows, Ewan McKendrick, and James Edelman, Cases and Materials on the Law of Restitution, 2nd ed. (Oxford: Oxford University Press, 2007) (Oxford: Oxford University Press 1997), 597. 
use the sum to bet on the trading of shares using inside information. The agreement between the two men was a contract to commit a crime and was itself a criminal conspiracy (the offense of insider dealing is contrary to $\S 52$ of the Criminal Justice Act 1993). The agreement was not carried out because the information was not forthcoming.

Nonetheless, Mr. Mirza did not return the money to Mr. Patel, who then brought a claim against Mr. Mirza, who contended that the claim should be dismissed because of the arrangement's illegal nature. In this case, Supreme Court decided in favor of restitution despite the illegal contract on which the claim for enrichment was based. Although the UKSC decision was unanimous, the Justices did not agree on the reasoning. In fact, the majority favored a discretionary approach based on a "range of factors," while the minority would have preferred a rule-based approach.

The majority chose a "flexible" approach constructed on a "range of factors," summarized by Lord Toulson as follows:

The essential rationale of the illegality doctrine is that it would be contrary to the public interest to enforce a claim if to do so would be harmful to the integrity of the legal system (or, possibly, certain aspects of public morality, the boundaries of which have never been made entirely clear and which do not arise for consideration in this case). In assessing whether the public interest would be harmed in that way, it is necessary (a) to consider the underlying purpose of the prohibition which has been transgressed and whether that purpose will be enhanced by denial of the claim, (b) to consider any other relevant public policy on which the denial of the claim may have an impact and (c) to consider whether denial of the claim would be a proportionate response to the illegality, bearing in mind that punishment is a matter for the criminal courts. Within that framework, various factors may be relevant, but it would be a mistake to suggest that the court is free to decide a case in an undisciplined way. The public interest is best served by a principled and transparent assessment of the considerations identified, rather by than the application of a formal approach capable of producing results which may appear arbitrary, unjust or disproportionate. ${ }^{141}$

Patel v. Mirza is the result of a long and continuous process of critical rethinking on the illegal contract that emerged in case law (i.e., from a number of cases in the 1980s and 1990s that rejected the application of the strictest version of the illegal doctrine $)^{142}$ and through the work of legal scholars ${ }^{143}$ and the Law Commission. ${ }^{144}$

141 Patel v. Mirza, 2016, UKSC 42, par. 120.

142 See Hugh. G. Beale and Joseph Chitty, Chitty on Contracts (General Principles), vol. 1 (London: Sweet \& Maxwell, 2018) § 16-012 (providing all relevant references and further details on the developments of the law of illegal contracts in English law).

143 Andrew Burrows, A Restatement of the English Law of Contract, 2nd ed. (Oxford: Oxford University Press, 2016), $221 \mathrm{ff}$.

144 See at least the final report: “The Illegality Defence," (The Law Commission, 2010). 
This decision aims to seek balance and proportionality among the remedies, the circumstances of the case and the interests at stake, following a flexible approach, disclosing the criteria that drive these choices and thus avoiding criticism of excessive unpredictability or uncertainty on the outcome of the award. ${ }^{145}$

Long before (as far back as 1970), ${ }^{146}$ New Zealand became the first Commonwealth jurisdiction to enact legislation intended to bring about a comprehensive reform of the law relating to illegality in contracts. ${ }^{147}$ The Illegal Contracts Act of 1970 was based on the idea that even if some illegal contract should not be enforceable at law, in other cases, it is a just and proper way to give legal effects, in part or in full, to such agreements. ${ }^{148}$ According to the legislature, no rule-based approach would provide the flexibility needed for illegal cases; the result was to give the court a discretion to grant relief - by validating the contract or otherwise - in the appropriate case. ${ }^{149}$ The Illegal Contract Act of 1970 was repealed and replaced by subpart 5 of part 2 of the Contract and Commercial Law Act 2017 (CCLA), ${ }^{150}$ that reflects the previous rules. It grants the courts extensive powers to bring justice between the parties. ${ }^{151}$ Even if the starting point is that illegal contracts have no effect, ${ }^{152}$ the court may grant relief that it deems to be just, including (without limitation) restitution, compensation, variation of the contract, or validation of the contract in whole or in

145 For further details on the approach outlined in Patel $v$ Mirza, see the more recent case of Stoffel \& Co $v$ Grondona [2020] UKSC 42, where the UKSC affirmed that the application of this trio of considerations of Patel should not be a mechanistic process. Accordingly, the Court identified the policy considerations at stages (a) and (b) of the trio at a relatively general level. The court's task is to establish whether enforcing a claim that is tainted with illegality would be inconsistent with the policies to which the law gives effect or, where the policies compete, to decide where the balance lies. The court is not required to evaluate the underlying policies themselves and when considering proportionality at stage (c), it is likely that the court will need to look closely at the case before it. See also, the illegality defence in a clinical negligence case, Henderson $v$ Dorset Healthcare University NHS Foundation Trust [2020] UKSC 43.

146 After all, even if comprehensive reforms have not been enacted, signs of a certain disaffection to doctrine of illegality have been recorded for decades as witnessed. In this regard, the Law Reform Committee of South Australia 1977, the Law Reform Commission of British Columbia 1983, and the Ontario Law Reform Commission 1987 are noteworthy.

147 Buckley, Illegality and Public Policy, 305.

148 Jeremy Finn, Stephen M.D. Todd and Matthew Barber, Burrows, Finn \& Todd on the Law of Contract in New Zealand, 6th ed. (Wellington: LexisNexis NZ Ltd., 2018), 467.

149 Ibidem.

150 Contract and Commercial Law Act 2017 [CCLA], Subpart 5 - Illegal contracts, ss. 70-84. Available at the New Zealand legislature website, http://www.legislation.govt.nz/act/public/ 2017/0005/21.0/DLM6844033.html\#.

151 Finn, Todd and Barber, Burrows, Finn \& Todd, 467.

152 Contract and Commercial Law Act 2017, Subpart 5 - Illegal contracts, s. 73(1). 
part or for any particular purpose. ${ }^{153}$ According to $\S 78$, the court, in considering whether to grant relief, as well as the nature and extent of any relief to be granted, the court must have regard for the conduct of the parties. In the breach of enactment, consideration must be given to the object of enactment and the gravity of the penalty expressly established for any breach of the enactment, and any other matters that the court deems appropriate. ${ }^{154}$ However, relief is not granted if the court believes the granting of relief to be against the public interest. ${ }^{155}$

In the U.S., the effort for more flexibility could be seen in the change in the wording between the First (1932) and the Second (1981) Restatement of Contracts. More specifically, while the former - at section $598^{156}$ - stated as a general rule that a party to an illegal bargain could neither "recover damages for breach thereof nor, by rescinding the bargain, recover performance that he has rendered thereunder or its value," 157 the Second is in favor of a more balanced approach. ${ }^{158}$ Albeit the Restatement (Second) of Contracts $§ 197$ (1981) reaffirms that a party has no claim in restitution for performance that he has rendered under or in return for a promise that is unenforceable on the grounds of public policy, it (immediately in the same section) adds a necessary provision that allows restitution when its denial would cause disproportionate forfeiture. ${ }^{159}$ This article leaves a certain discretion to the court. Possible criteria for the judge to follow are indicated only in the Comments. According to the Comments, account will be taken of such factors as the extent of the party's deliberate involvement in any misconduct, the gravity of that misconduct, and public policy's strength. In the Comments, it is stressed that the exception is especially appropriate in the case of technical rules or regulations that are drawn so that their strict application would result in such forfeiture if restitution were not allowed. ${ }^{160}$ According to this more flexible approach, the Restatement (Third) of Restitution and Unjust Enrichment $\S 32$ (2011) provides that whoever renders performance under an agreement that is illegal or otherwise unenforceable for reasons of public policy, they may obtain restitution to the extent that the consideration of

153 Ibidem, s. 76(1).

154 Ibidem, s. 78.

155 Ibidem, s. 79.

156 Restatement (First) of Contracts $\S 598$ (1932).

157 For the exceptions to the general rule, see Restatement (First) of Contracts § 599-609 (1932).

158 See Ayres and Klass, Studies in Contract Law, 601.

159 Other main exceptions to the rule against restitution are provided in $\S 198$ in favor of a party that is excusably ignorant or in favor of a party that is not equally in the wrong, or in $\S 199$ in favor of the party that has withdrawn from a situation contrary to public policy.

160 Restatement (Second) of Contracts $\S 197$ (1981), Comment b, Exceptions. 
the claim for restitution does not defeat the intended policy of the legal prohibition. ${ }^{161}$

In Australia, greater flexibility has been achieved through case law: the courts have developed several exceptions ${ }^{162}$ to the general rule ex turpi causa so that in many circumstances, a party may be entitled to recover money paid or property transferred under an illegal contract. ${ }^{163}$

In Quebec, according to Art. 1699(2) civil code, the judge declaring a contract's nullity retains an exceptional discretion not to order restitution or to order only partial restitution, where full restitution leads to injustice. This discretion may be exercised in cases related to illegality. ${ }^{164}$

In all these systems, although with very different gradations, there has been a trend in favor of greater flexibility in remedies giving the judge the power to choose the most appropriate one. This choice is sometimes guided by clear and transparent criteria, sometimes entrusted to a more "open-ended discretion" of the judge or even delegated to the rule-exception game. In any case, pre-packaged solution, in which the mere presence of elements of illegality results in a lack of restitution as an automatism seems to be discarded.

\section{Conclusion: Legal Reductionism is not an Appropriate Answer}

This contribution has highlighted the difficulties of navigating through the fluid category of "illegal contracts." Within this dark forest, the present article seeks to

161 There could be two potential obstacles to the action for restitution. The first one is related to the policy that prohibits the transaction that, in case of incompatibility, prevails on the policy in favor of restitution. The second potential obstacle is the claimant's inequitable conduct that could preclude the assertion of a claim based on unjust enrichment. See Restatement (Third) of Restitution and Unjust Enrichment $\S 32$ and $\S 63$ (2011).

162 Des A. Butler et al., Contract Law Casebook, 3rd ed. (Oxford: Oxford University Press, 2018), 689.

163 Ibidem at 679 (explaining, for instance, that in Nelson v. Nelson, 1995, 184 CLR 538, 604-5, four situations in which courts will not refuse to grant relief despite the presence of illegality include: (a) where the claimant was ignorant or mistaken as to the factual circumstances that rendered the contract illegal (b) where the statutory scheme that rendered the contract illegal was enacted for the benefit of a class of which the claimant is a member (c) where the illegal agreement was induced by the defendant's fraud, oppression, or undue influence; and (d) where the illegal purpose has not been carried into effect).

164 Anne-Françoise Debruche et al., "Quebec," in International Encyclopedia of Law: Contracts, ed. Jacques H. Herbots (Alphen aan den Rijn, The Netherlands: Kluwer Law International, 2016), 138. 
highlight the importance of mitigating the principle of equivalence between an illegal contract and a null and void contract (even if not all violations of the law produce nullity) and then dismisses the rule in pari delicto as a general rule for the legal systems that still rely on it.

Two categories, relative nullity (or annullability/voidability) on the one hand and absolute nullity on the other, represent a great dichotomy arising at a time when the laissez faire approach prevented the state from intervening in contracts unless such a macroscopic violation jeopardized public interests. In such cases, the state intervened with the strongest sanction of nullity. However, because the state did not want to meddle with the overarching pillars of contract law (namely party autonomy and freedom of contract), this remedy was meant for a restricted nucleus of cases linked to such public interests and illegal contracts were part of it. Indeed, the individual whose interests were compromised had to promote an action of voidability. This dichotomy continues even though the legal context has completely changed, despite the state currently continuously intervenes to regulate, govern and conform contracts. ${ }^{165}$ And this has been going on not only in the name of public interest, but also in a series of too common situations where corporate interests are disguised as public ones. Changing the model, the nullity/annullability dichotomy no longer works well, resulting in an over expansion of the scope of nullity so as to address hypotheses that are outside its original scope. Responding to the infringement of mandatory rules with the total demolition of the contract, sanctioning such contracts with absolute nullity might be unnecessary when there are other options available. A nullity claim seeks a declaratory judgment according to which the contract is rendered void from the outset. The action can be asserted by any interested party and it can also be declared, sua sponte (“ex officio"), by the court. Contracts that are null and void cannot be validated, if not provide by law, and the action is not subject to law of limitation. In brief, nullity means the total destruction of the contract. ${ }^{166}$

Differently, the model laws examined (such as PICC, PECL, DCFR) offer a wide range of options to find a proportionality between the infringement of a mandatory rule, the circumstances of the case and its effects. Considering the contract valid consequently results in granting ordinary remedies (including the right to performance), avoiding the contract with retrospective effect (in whole or

165 It could be affirmed that in today's society, the increasing conformative regulation of economic relations gives rise to a very complex regulatory framework in which the discretion of regulatory bodies replaces private autonomy. However, as such framework does not account for the principle of good faith (particularly where it plays a fundamental role, such as in mostly civil law systems), it has become increasingly easy to violate laws and regulations.

166 While Italian law has been used as a "litmus test," it is also true for most legal system for claim regarding the declaration of nullity. This action is typical in the Italian and French legal systems. 
in part) or modifying it. The given set of criteria that a court must take into account (such as the purpose of the rule which has been infringed, the category of persons for whose protection the rule exists, any sanction that may be imposed under the rule infringed, the severity of the infringement, whether the infringement was intentional, whether one or both parties knew or ought to have known of the infringement, whether the performance of the contract necessitates the infringement, the parties' reasonable expectations, the closeness of the relationship between the infringement and the contract) could lead to a balanced decision without considerably undermining the predictability of law.

Once illegality leads to a null and void contract, a different kind of flexibility related to the restitution of the performances comes into play. The rigid approach is the one incorporated in the Latin maxims, ex turpi causa non oritur actio and in pari delicto potior est conditio defendentis, which represent the earliest common core of the Western legal tradition. This approach implies an automatism between illegal contract and lack of restitution when the parties are equally wrong. The soluti retentio rule is still in force, with singular characteristics, in different legal systems. One of them is the Italian legal system, where - according to Art. 2035 c.c. It. restitution is unavailable in cases where the parties are in pari turipitudinis. Even if Art. 2035 c.c. It. only applies to a minor subset (i.e. contracts against good morals) and not to all cases of illegality, and even if the rule has been criticized by Italian jurists and is only occasionally applied by the courts, a quite recent decision of the Italian Court of Cassation demonstrates that it is still "alive" with a formalistic and automatic approach. On the opposite side, English law - where traditionally illegality had been seen as an absolute bar to the action for unjust enrichment finally reached a flexible approach (after having struggled for many years with this issue) based on a range of factors, the "trio of necessary considerations," with the famous case Patel v. Mirza. ${ }^{167}$

The aspiration to find a balance struggles instead to be satisfied, on the one hand, if one stops at a simple formal qualification, which as it has been highlighted is not very fruitful, of the contract itself as "illegal" or "immoral," and on the other hand when the court is entrenched behind Latin maxims that, although repeated incessantly as a mantra, do not help in any way to understand the policy reasons behind the choices made.

Jurists cannot use legal reductionism to provide a simple answer to complex issues, because a complex issue requires an equally complex apparatus, even if complexity is more difficult to handle. A flexible approach in dealing with illegal contract cases requires the finding of a balance between the infringement of the law, its effects, the circumstances of the case. A given set of criteria to look at are

167 Finn, Todd and Barber, Burrows, Finn \& Todd, 467. 
important not to abdicate the principle of the rule of law and sink into a vague and unpredictable natural justice.

Current trends in European systems are moving in the direction of using general clauses as a means of achieving solutions characterized by a fair balance between the interests at stake and the proportionality between circumstances and remedies. ${ }^{168}$ The general clause on illegality should follow this course as to find the straightforward pathway that had been lost.

168 See Antonio Gambaro, “L’Arbitro Bancario Finanziario e l'exceptio doli," Banca borsa e titoli di credito 1, vol. 73 (2020): 146, 158. 